\title{
Topologisk og kombinatorisk syntaks som alvorligt ment skelnen
}

\section{Lars Heltoft}

Die topologische Tradition nach Paul Diderichsen nimmt unter den dänischen Generativisten eine zweideutige Position ein. In den zahlreichen Artikeln über die Satzklammeranalyse ist der Schluss unweigerlich derselbe: Was das topologische Modell und die topologische Analyse zu leisten hätten, sei schon in den verschiedenen Fassungen der ChomskyGrammatik geleistet; Satzklammermodelle seien, was Konstituenten, Felder und Plätze betrifft, als Notationsvarianten generativer Konstituentenstrukturen zu betrachten. Gegen diesen Reduktionsversuch richte ich unter der Überschrift "Topologische und kombinatorische Syntax als ernst gemeinter Unterschied" eine sowohl theoretische als empirische Kritik. In einer Analyse der dänischen Prädikativkonstruktion komme ich zu dem Schluss dass die lineare und wohl auch die kategoriale Identifikation von direkten Objekten und Prädikativen in der generativen Grammatik empirisch falsch ist, was seinerseits auch auf ihre theoretischen Grundannahmen zurückzuführen ist. Zweitens erlaubt das topologische Modell im Gegensatz zur generativen Grammatik eine notwendige Differenzierung zwischen klitischen Gliedern ohne und mit Topologie. Sowohl Reflexivpronomina als auch Personalpronomina lehnen sich klitisch an die Nexuskonstituente an; die Personalpronomina sind topologisch relevant, die Reflexivpronomina aber haben keine selbständige Topologie.

Nøgleord: topologi, felt, plads, konstituentstruktur, generativ grammatik, sætningsskema, prædikativ, neksus, klise, topologisk integritet, personlige pronomener, refleksive pronomener 


\section{Indledning}

Den generative grammatik i Skandinavien har løbende forholdt sig til Paul Diderichsen og sætningsskemaet og sat de to modeller i forhold til hinanden. Fælles for de bidrag jeg vil komme ind på her, er at man tolker sætningsskemaets pladser og felter som det samme som den generative grammatiks konstituenter, en opfattelse jeg mener er forkert. Den går helt tilbage til Ulf Telemans "Om Paul Diderichsens syntaktiska modell” (Teleman 1972 [1970]): Her forstås sætningsskemamodellen som en kontekstfri konstituentstrukturgrammatik med lineær binding (konkatenation) og rammes derfor af Chomskys kritik af sådanne allerede i Syntactic Structures. I 1980'erne knytter diskussionen sig især til udviklingen af government and binding-teorien fra en SVO-baseret model med engelsk som udgangspunkt til en version der kan beskrive de skandinaviske sprog og andre V2-sprog. Sætningsskemaet er bygget op omkring denne rækkefølge og drøftes derfor fortsat af den generative grammatik, med Platzack (1985, 1986, 1987), Bjerre m.fl. (2008) og Vikner (2015) som vigtige bidrag. Der er anerkendelse til de topologiske pointer hos Diderichsen, men den fælles forforståelse er at pladser/felter og konstituenter er det samme, og at Diderichsens model kan pakkes ind i den generative teori ${ }^{1}$ og ikke har noget at sige som ikke allerede er sagt der. Som Vikner (2015: 430) siger om begreberne pladser og felter i forhold til de anvendte konstituentstrukturer: "Der er (...) tale om en notationsforskel".

Dette synspunkt er blevet modsagt af John Ole Askedal (1986: 21-22), der peger på at feltanalysen "er et eget og selvstendig aspekt av den mer omfattende syntaktiske strukturbeskrivelse, og gjelder primært setningstopologien." Faren ved reduktionstesen er at den med Askedals ord "egentlig trivialiserer hele feltkonsepsjonen" (21), efter min mening således at dens deskriptive og metodiske styrke overses. Den afgørende funktionelle pointe i Diderichsens sætningsskema er at topologien er et selvstændigt udtrykssystem med egne indholdskategorier og indholdsvalg. I den generative grammatik er alle lineære forskelle samtidig hierarkiske forskelle, men Diderichsens grundlag er at linearitet og syntaktisk hierarki skal kunne skelnes fra hinanden således at en topologisk forskel ikke på forhånd er bundet op på en hierarkisk forskel. Forholdet mellem topologi og hierarki skal kunne studeres empirisk.

1 Herved forstås udelukkende de forudsætninger der refereres til i de nævnte arbejder fra Lund og Århus. Vikner (2015: 430) henviser til principles and parameters-teorien (Chomsky 1986) som forudsætning for de opstillede træer. 
I det følgende vil jeg sætte fokus på forholdet mellem det kombinatoriske niveau og det topologiske (ledstillingens) niveau. Det er et forsøg på at vise at og hvordan den generative kobling mellem hierarki og rækkefølge kan betyde at teorien kommer til at skygge for sig selv, ikke en form for mandjævning eller eksegese af den rette læsning af Diderichsen. Jeg mener der substantielt set er mindst tre hovedproblemer i diskussionen mellem dansk topologi og den generative grammatik. Den ene er problemet om fundamentfeltet, dets semantiske kodning og fundamentleddets syntaktiske status. Det er den mest komplicerede problematik, og den berøres sporadisk, men er ikke samlet på dagsordenen her ${ }^{2}$.

En anden problemstilling er analysen af prædikativet, dets syntaktiske funktion og topologi (3.1). Den giver rigelig anledning til at diskutere forholdet mellem kombinatorisk syntaks og topologi, og her er der overensstemmelse mellem sætningsskemaets traditionelle udformning og den generative teori. Diderichsens N i indholdsfeltet korreleres i (1) med den nederste VP-datter DP, der rummer det direkte objekt, se også (3). Diderichsen mener at prædikativet topologisk set er et nominalt led (EdG $\S 67)$; den generative analyse er for så vidt endnu mere traditionel, for her er der ikke tvivl om hverken konstituentstruktur eller rækkefølge: Direkte objekt og prædikativ analyseres på samme måde: Det transitive verbum har objektkomplement, kopula-verbet har prædikativet som komplement, og de syntaktiske træer og dermed positionerne er de samme. Eks. (1) viser ligheden.

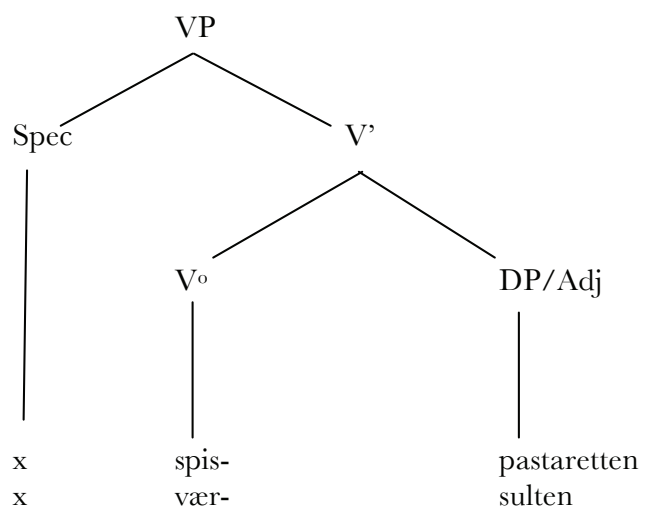

Figur 1. Direkte objekt og predikativ i en principles and parameter-analyse.

2 Jeg har skrevet om det i Festskrift till Christer Platzack (Heltoft 2003); mine synspunkter fremgår i øvrigt af GDS XVIII. 
Problemet er ikke nyt, men helt centralt (Heltoft 1993, 1995; GDS VII § 11.4), og her har en revision af Diderichsens analyse været nødvendig. Prædikativernes topologi er ikke den samme som objekternes, for med Diderichsens eget metodologiske udgangspunkt kan man vise at prædikativer og direkte objekter ikke har samme position. Objekter og prædikativer har heller ikke samme syntaktiske funktion og kan ikke indgå i den samme syntaktiske konfiguration. Det sidste har Diderichsen $(1946, \S 68)$ klart blik for:

"Prædikativer er Indholdsled, der angiver en Egenskab eller Tilstand, henh. et Navn paa et Substantial. De staar saaledes paa een Gang i Underordningsforhold til et Verbum og i Neksusforhold til et Substantial, der er Subjekt i Forhold til Prædikativet”

Der siges at være neksus (tovejs styring) mellem prædikativ og subjekt, en analyse der desværre er forsvundet i senere udgaver af $\operatorname{EdG}\left(1957^{2}\right.$ og 1962 3 ), men som jeg vil forsøge at præcisere i 3.1.

Det tredje hovedproblem er led uden topologi (3.2), en særtype af såkaldte klitiske led hvis eksistens modellen sådan set forudser eller åbner op for, men som aldrig ellers er diskuteret for alvor som særskilt problem. Det drejer sig for dansks vedkommende frem for alt om systemet af refleksive pronomener og deres syntaktiske realisation. Man har undret sig over placeringen af refleksive pronomener i eksempler som (2-4) og spurgt om der her skal oprettes en ekstra letledsplads.

(2) Her skal der snart slynge sig en å igen

(3) Der havde samlet sig 100000 mennesker på slotspladsen

(4) Der vil vise sig en ny stjerne på himlen

Før man kan overveje det, må man imidlertid afgøre om refleksiverne hører sammen med de øvrige lette pronominale led og opfører sig ligesom dem. Jeg viser i 3.2 at det gør de ikke.

\section{Diderichsens skelnen mellem topologisk og kombi- natorisk syntaks}

Som nævnt i indledningen opfatter den generative grammatik Diderichsens felter og pladser som ækvivalente med konstituentstrukturer og konstituenter. Følgende diagram (6) fra Bjerre m.fl. (2008) viser hvordan man sætter de gene- 
rative træer i relation til sætningsskemaet. Der er tre positioner i diagrammet der aldrig kan udfyldes på dansk, nemlig de to nederste VP-specifikatorer (DP'er) og kategorien I ${ }^{\circ}$, og på disse tre steder er de tomme pladser således ikke en del af dansk topologi. I sætningsskemaet er der ikke tomme pladser i denne forstand, for det registrerer kun det der kan have topologisk funktion i betydningen 'er udtryk for sætningsindhold på et andet niveau'.

I diagrammet antager man med Platzack (1985, 1986, 1987) og SAG (1999) at hovedsætnings- og bisætningsskema kan relateres systematisk til hinanden, således at hovedsætningens finitplads sættes lig med bisætningens subjunktionalplads. Grebet har den skønhed og gevinst at pladserne i skemaerne relateres tydeligt til hinanden. Skemaerne adskiller sig kun ved de to første placeringsmuligheder: Fundamentfelt og finitplads i hovedsætninger, subjunktionalplads (Subj) i bisætninger, se (5). Jeg undlader at tage stilling til om subjunktionens plads svarer til F eller v, jf. Heltoft (201 la) og Jørgensen (2000b).

(5) Illokutionære og subjektive pladser HS F v

BS Subjunktion $\mathrm{n} a$ Nægtelse A
Pladser for propositionelle led $\mathrm{V}$

A

A $\mathrm{vV}$ 
(6) $=($ Bjerre m.fl. 16)

(16) a.

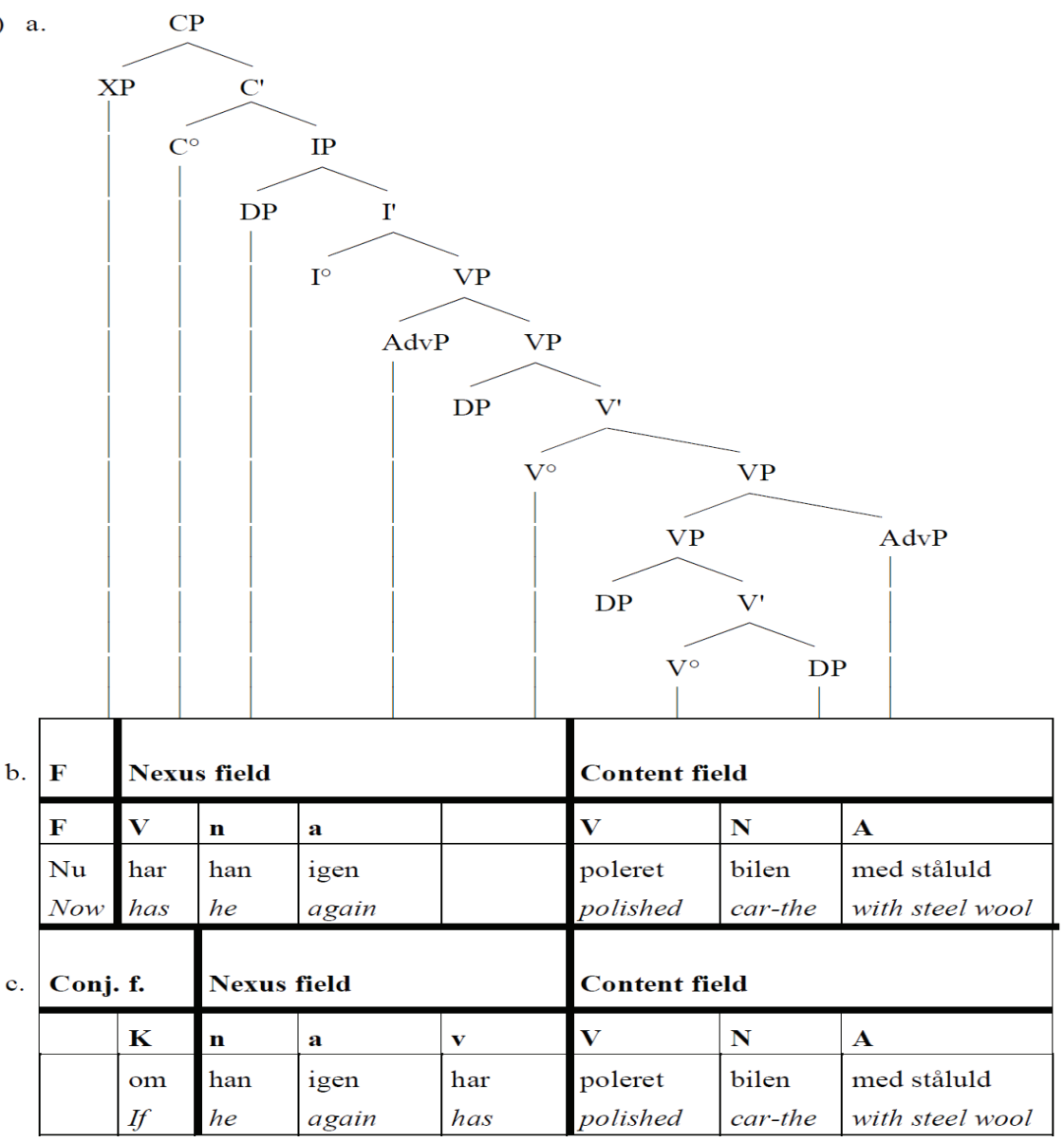

At relatere de to skemaer til hinanden er imidlertid ikke det samme som at vise at skemaerne er notationelle varianter af generative syntakstræer, for den kombinatoriske syntaks udgør et andet analyseniveau. Diderichsens position er kort og klart fremstillet i artiklen Logische und topische Gliederung des germanischen Satzes (Diderichsen 1966 [1943]). Her hedder det:

"Nach seiner Klassendefinition (infolge Brøndal: $r d$, d.h. zugleich relations-setzend und beschreibend) und seiner Spezialbedeutung (spezifische Fälle von Handlung, Vorgang, Prozess) hat das Verbum einen besonderen Reichtum an "Leerstellen" (Bühler), d.h. Möglichkeiten zur Verbindung mit Gliedern verschiedener Art." (s. 33) 
Verbets 'Leerstellen' dækker de udfyldningsmuligheder verbalstammen har ifølge sin betydning, og det giver god mening at forstå dette som en form for uudfoldet valensbegreb. Der er tre hovedtyper af led, på tysk benævnt som Gegenstandsglieder, Zustandsglieder og Umstandsglieder, altså:

Led der betegner genstande ('nominale led')

Led der angiver en tilstand ved et genstandsagtigt leds referent ('adjektiviske led')

Omstændighedsbetegnelser ('adverbielle led')

At dette er 'logische Gliederung', skal forstås semantisk. Den logiske ledtypologi skal altså redegøre for hvilke ledtyper der findes, hvad deres semantiske træk er, og hvilke af dem der kan udledes af verbalstammens egen betydning. En sådan kombinatorisk syntaks er en forudsætning for den topologiske analyse, men det er på ingen måde givet at forholdet mellem dem er ligefremt eller isomorft. Dette skal kunne undersøges empirisk.

\subsection{Dependensanalysen $\boldsymbol{i} \boldsymbol{E} d G$}

I EdG (§ 53) finder man elementerne til en kombinatorisk dependenssyntaks i form af de tre grammatiske relationstyper:
Relation: Neksus, hypotakse, paratakse
Produkt: $\quad$ Neksus, hypotagme, paratagme

her nævnt kort som forudsætning for den senere analyse af neksus- og hypotagmekonstruktioner i afsnit 3.1, hvor analyserne forklares. Denne tredeling ligger også til grund for syntaksanalysen i GDS (II, § 32), dog således at betegnelsen neksus ikke bruges, men erstattes af de hjelmslevske begreber katatakse og katatagme, jf. Heltoft (2013). Dependensanalysens elementer ligger parat i EdG, men den gennemføres ikke:

(a) Vi får ikke nogen præcis analyse af grænsen mellem hypotagmekonstruktion og frie led, og denne grænses afbildning i topologien, jf. at en mængde forskellige ledtyper hobes op på den formodede position $\mathrm{A}^{3}$; emnet er ellers i princippet meldt ud ved skellet mellem 'led der betegner genstande' og 'omstændighedsbetegnelser'.

3 Diderichsen selv (1966[1964]) og efter ham Erik Hansen (1970), senere Heltoft (1993 og 1995), GDS (2011) og Sten Vikner (2015) har påvist behovet for ændringer og udvidelser af især indholdsfeltet. 
(b) Diderichsen prøver ikke for alvor hvor langt neksusanalysen kan føres, fx i retning af en analyse af det der i moderne tid kaldes sammensat prædikat.

(c) Det er uklart hvordan der skelnes mellem en kombinatorik bestemt af stammesemantik (de nævnte 'Leerstellen'), altså valens i moderne terminologi, og en kombinatorik bestemt af kategoriernes generelle egenskaber. I GDS skelner vi efter Eisenberg (2004ab) mellem leksikalsk rektion (stamme styrer kategori) og kategorial rektion (kategori A styrer kategori B).

\subsection{Permutation og substitution}

I amerikansk strukturalisme spiller distributionsanalyser en central rolle i fastlæggelsen af konstituenters afgrænsning og identifikation. Samme distribution og komplementær distribution er de empiriske kriterier for at regne to størrelser til samme kategori.

Hos Diderichsen anvendes permutations- og substitutionstest også til identifikation af led og ledgrænser, men fremfor alt til svar på spørgsmålet om ledtyperne står på samme plads eller ej. For ham er disse test primært et kriterium for hvad der er topologiske led, dvs. hvad der kan udfylde de funktioner topologien har. En af de allervigtigste test er placering i det såkaldte fundamentfelt, først i fremsættende hovedsætninger. På dansk har alle topologisk relevante sætningsled mindst to placeringsmuligheder: sin karakteristiske plads og placering i fundamentfeltet, fx det direkte objekt: din bil skal du ikke polere med stäluld vs. du skal ikke polere din bil med ståluld; nogle frie adverbialtyper har tre eller endog fire placeringsmuligheder: de havde holdt ham hen med snak longe vs. de havde lange holdt ham hen med snak vs. de havde holdt ham lange hen med snak vs. lange havde de holdt ham hen med snak. I fundamentfeltet siges alle tre overordnede ledtyper (ANV) at kunne stå, og Diderichsen (1966 [1964]) stiller det op som i (7) (prikkerne betyder at kategorierne kan optræde rekursivt).

$\begin{array}{lllllllll}\mathrm{A} & & & & & & & \\ \mathrm{N} & & \mathrm{V} & \mathrm{N} & \text { A.. } & / & \text { V.. } & \mathrm{N} . . & \text { A.. } \\ \text { (V) } & & & & & & & & \end{array}$


Man kan tilføje betegnelserne for felter og pladser, de indsatte led sættes nu i kursiv:

$$
\text { F / }
$$

Neksusfelt

a

l

Indholdsfelt

$\begin{array}{lllllll}\mathrm{v} & \mathrm{n} & \mathrm{a} & \mathrm{V} & \mathrm{N} & \mathrm{A}\end{array}$

$\begin{array}{llllllll}A & & & & & & \\ \mathcal{N} & V & \mathcal{N} & A . . & & \text {.. } & \mathcal{N} . & A . . \\ V & & & & & \end{array}$

Af Hansen (1970) og af GDS (hvor det er udarbejdet mere konsekvent) fremgår oversigten ${ }^{4}$ i (9). Al rummer både sætningsadverbialer som sandsynligvis, formentlig, egentlig, desvarre og dialogiske partikler (DP) som jo, skam, nok, vel, vist, men de hører tydeligvis ikke til samme kategori. Ingen dialogiske partikler kan placeres i fundamentfeltet, det kan ethvert sætningsadverbial derimod, og de sidste er if. Diderichsen topologisk relevante led.

\begin{tabular}{llllllllllll}
$\mathrm{F}$ & \multicolumn{1}{c}{ Aktualfelt } & \multicolumn{1}{c}{ Indholdsfelt } & & & \\
$\mathrm{X}$ & $\mathrm{V}$ & $\mathrm{N} 1$ & $\mathrm{~A} 1$ & $\mathrm{~V}$ & $\mathrm{~N} 3$ & $\mathrm{~N} 2$ & $\mathrm{~A} 3$ & $\mathrm{P}$ & $\mathrm{Adv}$ & $\mathrm{A} 2$ \\
\hline & & & & & & & & & & \\
$S$ & $V$ & $S$ & $D P$ & $V$ & $I O$ & $D O$ & MA & P & Adv & $F A$ \\
$S A$ & & & $S A$ & & & & & & & $M A$ \\
$F A$ & & & $F A$ & & & & & & & \\
$M A$ & & & $M A$ & & & & & & & \\
$V$ & & & & & & & & & & \\
$I O$ & & & & & & & & & & \\
$D O$ & & & & & & & & & & \\
$P$ & & & & & & & & & & \\
$A d v$ & & & & & & & & & &
\end{tabular}

Efter denne opstilling kan placering være indholdsmæssigt relevant ${ }^{5}$ på 2 måder:

(a) Den kan pege indeksikalsk på den hierarkiske struktur og i denne forstand være dens udtryk. Relationen kan være mere eller mindre komplet eller isomorf.

$4 \quad \mathrm{~A} 1$ = plads for dialogiske partikler, sætningsadverbialer og frie adverbialer; $\mathrm{A} 2$ = plads for frie adverbialer; A3 = plads for mådesadverbial; Adv = (plads for) faste adverbialer, $\mathrm{N} 1$ = plads for subjekt (S), N2 = plads for direkte objekt (DO), N3 = plads for indirekte objekt (IO), P = Prædikativ. De topologiske forskelle inden for Aler udeladt.

5 Der er ikke plads til analysen af dialogpartiklerne her. De klitiserer i sætninger til neksusleddet eller til finittet, men de forskellige klitiske positioner er forbundet med betydningsforskelle: Modsætningen mellem Der kommer Per Degn jo og Der kommer jo Per Degn er kodet informationsstrukturelt, jf. Jørgensen 1991, Heltoft 1992, Jørgensen 1996. 
(b) Den kan være udtryk for egne symbolske kodninger, dvs. for kodninger der ikke er bundet op på den syntaktiske struktur. Fundamentfeltets udfyldningsmuligheder er krafteksemplet på dette, se videre Heltoft (2003) og GDS XVIII § 4-5.

\section{Eksempler på forskellen mellem topologi og syntaks}

Topologien udtrykker den syntaktiske organisering af sætningen, dvs. den er et udtrykssystem der delvis er en isomorf manifestation af den syntaktiske kombinatorik. Diderichsen (1966 [1964]: 369) viser hvorledes nominale, verbale og adverbielle led kan fordeles i neksusfeltet og indholdsfeltet på en måde der et stykke ad vejen afspejler sætningens syntaktiske dependens: neksusleddet står i neksusfeltet/aktualfeltet og verbalhelheden (verbalhypotagmet) står i indholdsfeltet.

EdG skelner ikke mellem de adverbielle led der er valensled (de middelbare objekttyper og de styrede lokale led) på den ene side, og på den anden side de frie adverbialer der ikke er valensled (omstændighedsbetegnelserne). Det er et sted hvor det pædagogisk håndterbare vinder over det deskriptivt adækvate, og hovedproblemet i analysen af indholdsfeltet er selve identifikationen af de syntaktisk og topologisk relevante kategorier, især analysen af prædikativet.

Generative grammatikere skaber ofte overblik over de hierarkiske forskelle i træstrukturerne ved at beskrive dem som en form for sætningens lagdeling (jf. Dik 1997), dog med færre indholdsbestemmelser. Disse er omtrent på samme præcisionsniveau som indholdsbestemmelserne af de diderichsenske felter og må snarest opfattes som en hensigtserklæring om de funktionsmuligheder der kan præciseres ved en egentlig indholdsanalyse. Diagram (10) er fra Bjerre m.fl. (2008).

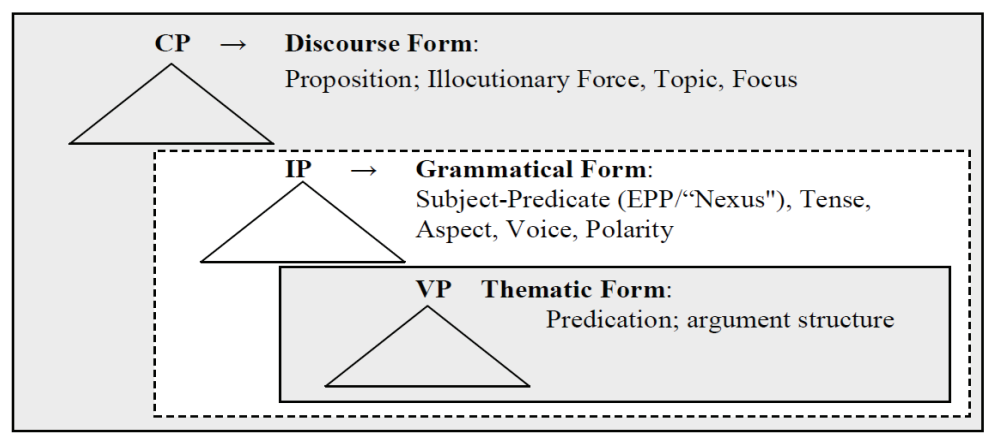




\subsection{Analysen af pradikativets konstruktion og placering}

I den generative model genereres prædikativet i den nederste del af træet, den der genererer prædikatet (verbalet) og dets tilhørende argumentstruktur. Direkte objekt og prædikativ genereres på samme sted i træet og må således høre til samme kategori med analog syntaktisk struktur, jf. (1).

Her er der en anden ejendommelighed. Strukturen følger af de basale formelle syntaktiske opbygningsprincipper, således at subjektet genereres i en struktur der forudsætter at det også på prædikationsanalysens niveau har særstatus i forhold til objekt og andre styrede led og altså ikke er komplement til verbalet ${ }^{6}$. Strukturen (11) forudsættes overalt i hierarkiet, også der hvor den ikke kan udfyldes,

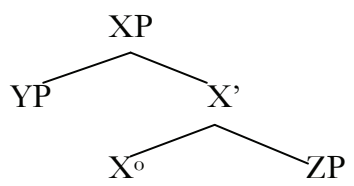

som her på det nederste, prædikationsanalytiske niveau. Også Platzacks fremstilling af den minimalistiske teori (2010: 69-70) synes at forudsætte at søsteren til $\mathrm{X}^{\circ}$ er et komplement.

Set ud fra et valensanalytisk synspunkt har subjektet imidlertid ikke nogen særstatus. Det styres ved stammerektion på samme måde som objektet, i (1213) som et krav om at subjektsreferenten skal være en person/personer. Både subjekt og objekt forudsætter på dette niveau hver sit Leerstelle i verbalets stamme. I GDS vises dette i simple dependensdiagrammer som (14), der viser ren leksikalsk rektion.

de skyder pianisten

(13) de skyder på pianisten

6 Betingelserne for at analysere noget - frem for alt subjektet - som en specifier forekommer mig ikke klare. Forskellen mellem subjekt og objekt er et spørgsmål om kategorial styring, ikke om forskellen mellem modifikation og valens. Begge ledtyper er aktanter med leksikalsk styring. 


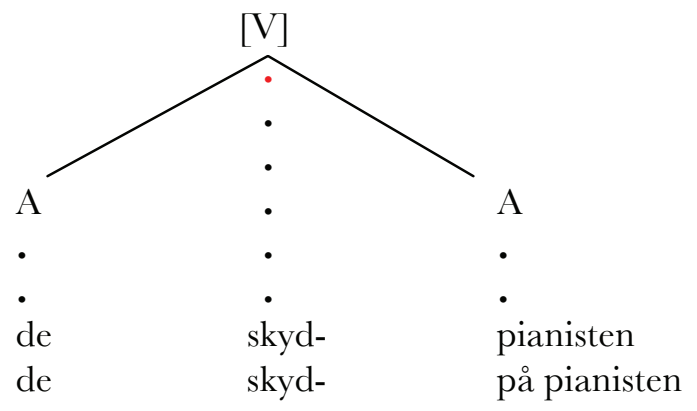

I dependensdiagrammer som (14) betyder 'skrå streg' hypotakse eller envejs styring, og verbalstammen styrer således sine argumenter.

Den generative analyse forudsætter at kopulaverber som vare og blive kan beskrives på samme måde som i (14), men dette holder ikke empirisk, jf. Heltoft 1993, 1995 og GDS kap. VII § 11.4. Kopula styrer aldrig sit subjekt ved stammerektion; valensstyringen er ikke mellem kopula og subjekt, men mellem prædikativ og subjekt. og det er, som jeg vender tilbage til, også umuligt at opfatte kopulas forhold til prædikativet som en envejs relation mellem kerne og komplement (head and complement).

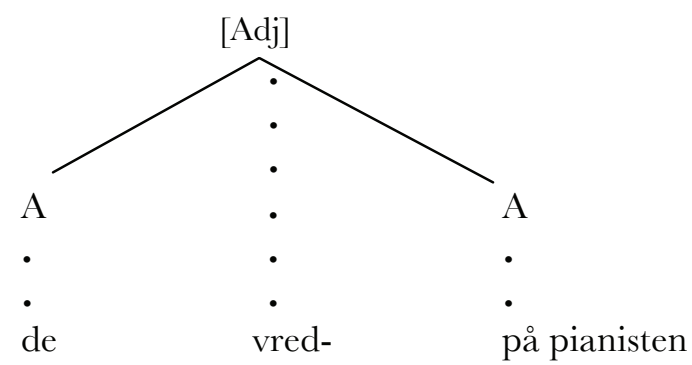

Relationen mellem kopulaverbum og prædikativ er derimod en tovejs relation: Kopulaverbet skal udfyldes med et prædikativ, men prædikativet kalder på sin side på et kopulaverbum, og denne dobbelte styringsrelation er det der hedder neksus eller katatakse. Tilsammen danner kopula og prædikativ en kompleks prædikatshelhed på højere niveau som ingen af kategorierne kan danne alene. Der bliver således på rent Diderichsen-grundlag en dobbelt neksuskonstruktion: først en mellem kopula og prædikativ, og dernæst mellem denne sammensatte prædikatshelhed og subjektet (den sidste svarende til Diderichsens neksus mellem subjekt og finit verbal), vist som i GDS ved 
vandrette linjer mellem kategorisymboler. Den syntaktiske relation mellem kopula og prædikativ svarer da til relationen mellem temporalt hjælpeverbum og infinit verbal, som angivet i (16), hvor $\operatorname{AUX}(\mathrm{K})=$ kopula, $\operatorname{AUX}(\mathrm{T})$ $=$ temporalt hjælpeverbum.

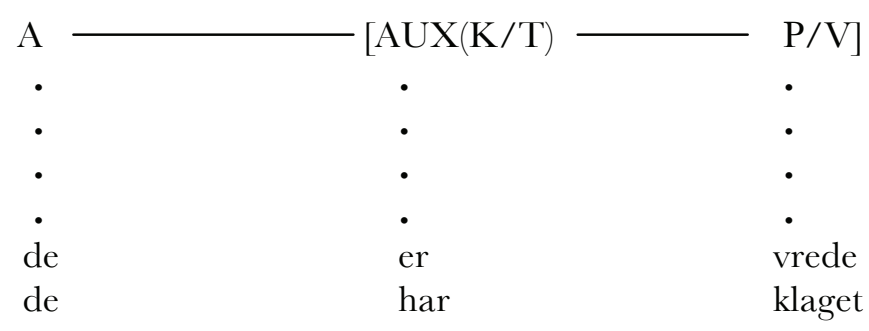

Prædikativet er syntaktisk set ikke et argument, og dets funktion kan ikke på nogen måde ækvivaleres med objekters. Den traditionelle analyse og den generative analyse kommer til kort her: I det sammensatte prædikat er det prædikativet der har valensfunktionen, og kopulaverbet er nødvendigt som bærer af finithed; men direkte objekter er argumenter i prædikationen og er ikke valensuddelere.

Bemærk at subjektets særstatus i et sprog som dansk fastholdes, dog netop ikke på valensniveauet, men på det man med Diderichsen kunne kalde aktualiseringsniveauet i sætningen, der hvor dens forankring udtrykkes. I modsætning til valensrelationerne er dette et rent kategorialt syntaktisk forhold, jf. (16).

Hvordan forholder disse eksempler på semantiko-syntaktisk ledanalyse sig så til udtrykssystemerne? Der er grund til at minde om at enhedstrykssystemet entydigt kategoriserer prædikativkonstruktioner sammen med perifrastiske verbalkonstruktioner og inkorporation (GDS VII § 22, XV § 14; Thomsen 1992) og ikke sammen med objekter.

(17a) de ${ }^{\mid}$skød pia'nisten

(17b) de Iskød på pialnisten

men klart enhedstryk i både (18a) og (18b).

(18a) de ${ }_{\mathrm{o}} \mathrm{blev}{ }^{\mathrm{I}}$ vrede på hende

(18b) de har 'buhet af hende 
Jf. ligeledes klare kontrasteksempler som (19) og (20):

(19) de ${ }_{\mathrm{o}}$ stillede 'blomsterne $\left.\mathrm{i}\right|^{\prime}$ vinduet

(2 valensled, sms. prædikat stillede-[i vinduet] (= satte til skue for at sælge)

(20) de Istillede 'blomsterne $\mathrm{i}$ | vinduet (3 valensled)

I det centrale udtrykssystem, topologien, skal direkte objekt og prædikativ ikke have samme lineære analyse, sådan som de automatisk får det i den generative model. Prædikativer står ikke på DO-pladsen (Heltoft 1993, 1995, GDS 2011), men to pladser til højre herfor.

(21a) Hun var blevet tidligt student

(21b) Hun var blevet uventet ('uden at man ventede det') vred på pianisten

(21c) Hun havde skudt uventet på pianisten

(21d) *Hun havde skudt uventet pianisten

Efter denne analyse (GDS XV § 14) viser den syntaktiske forskel mellem prædikativer og objekter sig også positionelt, nemlig ved en vidtstrakt isomorfi mellem verbal og ikke-verbal opbygning af hovedprædikatet i sammensat prædikation og placering i V, henholdsvis P. Kun i passivkonstruktioner og et mindretal af konstruktioner som få-konstruktion (vist i (22)) og objekt med verbal infinitiv kan infinittet stå på pladsen $\mathrm{P}$.

\begin{tabular}{|c|c|c|c|c|c|}
\hline (22) & $\mathrm{V}$ & DO & MA & $\mathrm{P}$ & ML \\
\hline Hun var & blevet & & tidligt & student & \\
\hline Hun var & blevet & & pludselig & vred & på pianisten \\
\hline Han havde & skudt & & uventet & & på pianisten \\
\hline Hun var & kommet & & for sent & i skole & \\
\hline Han havde & gået & & fire år & i gymnasiet & \\
\hline Hun var & blevet & & sent & moden & \\
\hline Hun havde & lukket & skabet & hermetisk & til & \\
\hline Greven har & kastet & Griseldis & brutalt & ud & af sovekammeret \\
\hline Han skulle & køre & bilen & hurtigt & hen & til værkstedet \\
\hline Hun havde & fået & bordet & smukt & restaureret & \\
\hline Det var ikke & blevet & & ordentligt & annonceret & \\
\hline
\end{tabular}


I forhold til diagrammet i (9) er Erik Hansens skelnen mellem P og Adv (faste adverbialer) erstattet af en analyse der skelner mellem $\mathrm{P}$ og ML (= middelbare valensled). Store dele af de traditionelle faste adverbialer er semantiske prædikater i sammensatte prædikater og står på P. På ML står de middelbare valensled: middelbare objekter og styrede lokale led.

Denne analyse viser topologiens indeksikalske funktion. Hvad der semantisk fungerer som prædikat, står på samme topologiske plads; også de nominale led behandles gennem en lignende isomorf afbildning: Alle objekter der består af en DP, står på pladserne for objekter, alle middelbare valensled, der jo er PP'er, står på pladsen ML.

Eksemplet viser smukt hvorledes syntaksens opbygning kan vises at have et udtryksmæssigt korrelat i topologien, et ekstra, delvis redundant udtryksniveau. Vi ved fra den klassiske fundamentanalyse at topologien kan udtrykke symbolsk betydning, nemlig illokutionær ramme; der mangler nu en analyse af led med manglende topologisk relevans eller som udtrykt i Heltoft (201 lb): manglende topologisk integritet.

\subsection{Led uden topologisk integritet}

I Heltoft (201 lb) har jeg argumenteret for en analyse af klitiske pronomener under synsvinklen topologisk relevans, indfanget under begrebet topologisk integritet. Tryksvage pronominale former der ikke er subjekt, står i vsahovedsætninger klitisk til neksusleddet (2011b: 61-79), men da de kan stå i fundamentfeltet, anses de for at have topologisk integritet, altså at kunne bidrage til at udtrykke topologiske modsætninger som kontrasten mellem tomt og udfyldt fundamentfelt.

$$
\begin{aligned}
& \text { den 'tror jeg altså ikke på } \\
& { }_{0} \text { det I gjorde jeg først heller ikke Iselv }
\end{aligned}
$$

Derimod har refleksive pronomener ikke topologisk integritet ${ }^{7}$. De kan ikke stå i fundamentfeltet, og de kan heller ikke på anden måde vises at fylde en plads i sætningsskemaet. Nøgleeksempler er de nævnte tilsyneladende marginale eksempler (2)-(4):

7 Jørgensen (2000a) konkluderer (med min terminologi) at alle tryksvage pronomener mangler topologisk integritet. Jeg mener der skal skelnes mellem refleksive og ikke-refleksive pronomener på dette punkt. 
(2’) Her skal der snart slynge sig en å igen

(3’) Der havde samlet sig 100000 mennesker på slotspladsen

(4’) Der vil vise sig en ny stjerne på himlen

De viser at sig ikke kan stå enklitisk på objektspositionen, for dér står allerede indholdssubjektets objektmanifestation. At oprette en letledsposition til dem netop her ville være et rent ad hoc-foretagende. Analysen skal således ikke tilskrive refleksiver nogen topologisk funktion, og de står som klitika i denne strengere forstand. De refleksive pronomener udgør således et separat paradigme (Heltoft 2011 b: 75), der skal holdes adskilt fra de trykreducerede pronomener på letledspladsen L, og refleksivformerne mig, dig, sig, osv. står aldrig på L. De refleksive former kan ikke genereres på nogen objektsplads, og de kan ikke optage nogen topologisk identificerbar funktion andre steder i træet. De kan heller ikke opfattes som bøjningsformer af verbet, for de klitiserer ikke til verbalstammen, men til neksusleddet.

Som jeg ser det, udgør beskrivelsen af de to typer klitiske pronomener en vanskeligt overstigelig barriere for den generative model, i hvert fald som den er afgrænset her. Der er ikke noget neksusled refleksiver og lette pronomener kan klitisere til, og refleksivformerne kan ikke genereres som bøjningsformer af verbet. I den generative model skal refleksivformerne enten være bøjningsformer eller genereres som objekter, dvs. i objekt-DP'en i (1). Med den første analyse forudsiger man at refleksiverne ikke kan skilles fra deres verbalstammer (for det kan fleksiver ikke), og det er, som (25b) vs. (25e) viser, forkert. Med objektanalysen forudsiger man at de har argumentstatus, men de simple refleksive pronomener angiver jo netop at argumentstatus fravælges, jf. GDS III § 27.2 og Hvilshøj 1998). Hvis en verbalstamme har et Leerstelle/ slot til et objekt, angiver refleksivpronomenet at denne kombinationsevne forsegles: en form for medial konstruktion der reducerer valensen med den pågældende aktant. 


$\begin{array}{llllllll}\text { F } & \mathrm{V} & \mathrm{S} & \mathrm{L} & \mathrm{a} & \mathrm{V} & \text { DO } & \text { FA }\end{array}$

(25a) [jeg barberer]-mig

lige

[barberer

du]-dig

lige?

(25c) [jeg [har

(25d) *mig

barberer

lige barberet]]-mig

igen

*barberede-dig du

lige

lige?

(25f) Chaplin barberede

ham jo

barberede

Chaplin ham ikke?

(25h) Chaplin måtte selv barbere

ham/Hynkel

(25i) ham

barberede

han selv

Den refleksive argumentform hedder mig selv/dig selv/sig selv, osv. (jf. Hvilshøj 1998). Forudsigeligt nok er (26c) semantisk umulig, fordi sig angiver at der intet objektargument skal realiseres syntaktisk eller semantisk, mens de nægtende led ikke Hynkel, forudsætter at der er et objektargument.

(26a) Han barberede Hynkel, ikke sig selv

(26b) Han barberede sig selv, ikke Hynkel

(26c) *Han barberede sig, ikke Hynkel

At generere dem i objektposition ville også tilskrive dem en topologisk funktion som de ikke kan have, og man kan efter alt hvad jeg ved, ikke ændre deres semantiske status ved at flytte dem til positioner højere oppe i træet.

Med analysen af trykreducerede pronominale led og refleksive led har vi da to typer af klise til en konstituent. Begge skal stå i kontaktstilling til neksusleddet, forstået som det samlede kompleks af subjekt og prædikatsled, men kun de trykreducerede objekter skal indtage en position.

Hvordan kan dette tackles i den generative teori? Man kan sammenligne med analysen af genitiv som klitikon i (27), uden at gå ind i en nærmere vurdering. Her angiver $-s$ en relation mellem referenten i en DP (svarende til et subjekt) og referenten i et NP-komplement; i min sprogbrug er $-s$ et kerneled med relation til to argumenter, dvs. det har prædikatsstatus, jf. at Vikner (2014: 204f.) udtrykkelig paralleliserer $\mathrm{D}^{\circ}$ med $\mathrm{I}^{\circ}$, altså med finittet i fx fransk. 
(27)

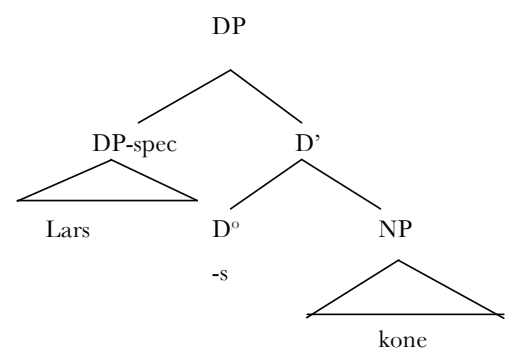

Denne mulighed står ikke åben som forklaring på disse pronominale ledtyper. De er ikke prædikater, og der er ingen konstituent de kan være klitiske til. Slet intet neksusled.

\section{Konklusion}

De grundlæggende synspunkter bag Diderichsens model er på ingen måde forældede, det er kun bestemte udmøntninger af den. Den kan fortsat udfordre den generative teori og pege på steder hvor sidstnævntes grundantagelser fører til vanskeligheder. Modellen og de analyser den giver mulighed for, kan ikke reduceres til den generative models analyser, men er tværtimod et godt udgangspunkt for udviklingen af en teori der for alvor skelner mellem kombinatorisk og topologisk syntaks.

\section{Henvisninger}

Askedal,J.O. (1986). Topologisk feltanalyse, koderingssystemer og pragmatiske funksjoner, $\mathcal{N y S}$ 16/17, 18-55.

Bjerre, T., et al. (2008). Points of convergence between functional and formal approaches to syntactic analysis, Working Papers in Scandinavian Syntax 82, 131-166.

Bjerrum, A., et al. (red.). (1966). Paul Diderichsen. Helhed og struktur. Udvalgte sprogvidenskabelige afhandlinger. København: Gads Forlag.

Chomsky, N. (1986). Barriers. Cambridge (Mass.): The MIT Press.

Diderichsen, P. (1946 [1957², 1962³]). Elementer dansk Grammatik. København: Gyldendal.

Diderichsen, P. (1966a [1943]). Logische und topische Gliederung des germanischen Satzes, i A. Bjerrum, et al. (red.), 52-63. 
Diderichsen, P. (1966b [1964]). Sætningsleddene og deres stilling - 30 år efter, i A. Bjerrum, et al. (red.), 364-379.

Dik, S.C. (1997). The Theory of Functional Grammar 1-2. Udg. af K. Hengeveld. Berlin: Mouton de Gruyter.

EdG = Diderichsen, P. (1946).

Eisenberg, P. (2004a). Grundriß der deutschen Grammatik. Band 1. Das Wort. Stuttgart, Weimar: Metzler.

Eisenberg, P. (2004b). Grundriß der deutschen Grammatik. Band 2. Der Satz. Stuttgart, Weimar: Metzler.

Fortescue, M., P. Harder \& L. Kristoffersen (red.) (1992). Layered Structure and Reference in a Functional Perspective. Papers from the Functional Grammar Conference in Copenhagen 1990. Amsterdam/Philadelphia:John Benjamins. GDS = Hansen, E. \& L. Heltoft (2011).

Hansen, E. (1970). Sætningsskema og verbalskemaer, NyS 2, 116-137.

Hansen, E. \& L. Heltoft (2011). Grammatik over det Danske Sprog I-III. København \& Odense: Det Danske Sprog- og Litteraturselskab \& Syddansk Universitetsforlag.

Heltoft, L. (1992). The Topology of Verb Second and SVO Languages. A Study in the Sign Functions of Word Order, i M. Herslund (red.) Word Order. Two Studies on Central Issues in the Syntax of Danish and French. Copenhagen Studies in Language 15. København: Handelshøjskolens Forlag, Nyt Nordisk Forlag Arnold Busck, 13-64.

Heltoft, L. (1993). Revision af indholdsfeltet, i M. Kunøe \& E. Vive Larsen (red.) 4. Møde om Udforskningen af Dansk Sprog (MUDS). Århus: Institut for Nordisk Sprog og Litteratur, Aarhus Universitet, 119-133.

Heltoft, L. (1995). Danish Predicative Adjectives and Adverbials as Valency Bearers, i L. Schøsler \& M. Talbot (red.) Studies in Valency I. [= Rask Supplement Vol. 1]. Odense: Odense University Press, 211-235.

Heltoft, L. (2003). Verb Second - a Content Analysis, i L.-O. Delsing, et al. (red.) Festschrift for Christer Platzack 18. November 2003 Vol. 2. Lund: Institutionen för nordiska språk, Lunds universitet/Department of Scandinavian Languages, Lund University, 151-157.

Heltoft, L. (2011a). Word order change as grammaticalisation: Paradigm structure and change in Scandinavian, i J. Nørgård-Sørensen, L. Heltoft \& L. Schøsler (2011) Connecting Grammaticalisation. Amsterdam/Philadelphia: John Benjamins, 171-235.

Heltoft, L. (201 1b). Lette pronomeners placering: klise og topologisk integritet, i P. Durst-Andersen \& H.H. Müller (red.) Ny Forskning i Grammatik 18, 61-80. 
Heltoft, L. (2013). Om neksusbegrebets nødvendighed, i L. Falster Jakobsen, et al. (red.) Ny forskning i grammatik 20, 109-128.

Hvilshøj, U. (1998). Refleksivitet $i$ dansk. Sig og sig selv i et typologisk perspektiv. Speciale, Københavns Universitet.

Jørgensen, H. (1991). Om de danske personlige pronominer, Danske Studier 1991, 5-28.

Jørgensen, H. (1996). Om adverbialled mellem det finitte verbal og subjektpladsen i danske hovedsætninger, Selskab for Nordisk Filologi. Arsberetning 1994-95, 76-90.

Jørgensen, H. (2000a). Begrebet "klisis" og dets anvendelse på analysen af de danske letled. Studier i nordisk 1998-1999, 37-50.

Jørgensen, H. (2000b). Indforing $i$ dansk syntaks. Aarhus Universitet. Tilgængelig online: http://www.hum.au.dk/engelsk/engsv/papers/joer00b.pdf.

Platzack, G. (1985). A Survey of Generative Analyses of the Verb Second Phenomenon in Germanic. Nordic Fournal of Linguistics 8(1), 49-73.

Platzack, C. (1986). Diderichsens positionsschema och generativ transformationsgrammatik, $\mathcal{N y}$ S 16/17, 161-170.

Platzack, C. (1987). Bisatser, huvudsatser och andra satser, i U. Teleman (red.). (1987), 79-86.

Platzack, C. (2010). Den fantastiska grammatiken. En minimalistisk beskrioning av svenskan. Stockholm: Norstedts.

SAG = Teleman, U., S. Hellberg \& E. Andersson (1999).

Teleman, U. (1972[1970]). Om Paul Diderichsens syntaktiska modell, i U. Teleman (1972), 33-57.

Teleman, U. (1972). Tre uppsatser om grammatik. Lundastudier i nordisk språkvetenskap. Serie C Nr 5. Lund: Studentlitteratur.

Teleman, U. (red.) (1987). Grammatik på villovägar. Skrifter utgivna av Svenska språknämnden 73. Solna: Esselte Studium.

Teleman, U., S. Hellberg \& E. Andersson (1999). Svenska Akademiens Grammatik 1-4. Stockholm: Svenska Akademien.

Thomsen, O. Nedergaard (1992). Unit Accentuation as an Expression Device for Predicate Formation. The Case of Syntactic Noun Incorporation in Danish, i M. Fortescue, P. Harder \& L. Kristoffersen (red.) (1992), 173-229.

Vikner, S. (2007). Teoretisk og komparativ syntaks, i H. Jørgensen \& P. Widell (red.) Det bedre argument - Festskrift til Ole Togeby, 7. marts 2007. Wessel \& Huitfeld, Århus, 469-480. Tilgængelig online: www.hum.au.dk/engelsk/ engsv/papers/vikn07a.pdf. 
Vikner, S. (2014). Possessorens status inden for nominalgruppen, i M. Birkelund, et al. (red.) Ny forskning i grammatik 21, 193-211.

Vikner, S. (2015). Dansk sætningsstruktur - et generativt vs. et Diderichsenperspektiv, i I. Schoonderbeek Hansen \& T. Thode Hougaard (red.) 15. Møde om Udforskningen af Dansk Sprog (MUDS), Århus: Institut for Kommunikation og Kultur, Aarhus Universitet, 429-449. 